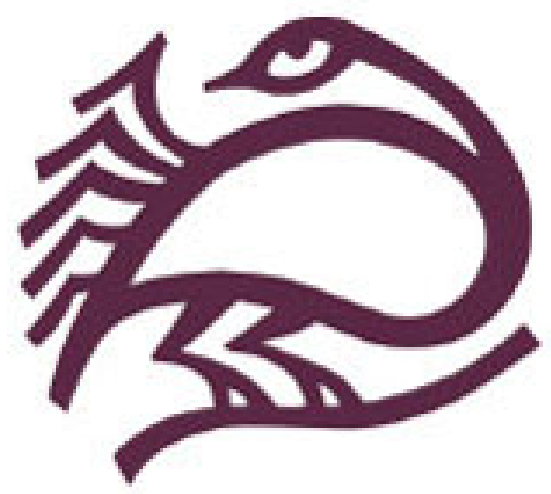

Post-Zionist Critique on Israel and the Palestinians Part II: The Media Author(s): Ilan Pappe

Source: Journal of Palestine Studies, Vol. 26, No. 3 (Spring, 1997), pp. 37-43

Published by: University of California Press on behalf of the Institute for Palestine Studies

Stable URL: http://www.jstor.org/stable/2538155

Accessed: 28/03/2014 10:34

Your use of the JSTOR archive indicates your acceptance of the Terms \& Conditions of Use, available at http://www.jstor.org/page/info/about/policies/terms.jsp

JSTOR is a not-for-profit service that helps scholars, researchers, and students discover, use, and build upon a wide range of content in a trusted digital archive. We use information technology and tools to increase productivity and facilitate new forms of scholarship. For more information about JSTOR, please contact support@jstor.org. 


\title{
Post-Zionist Critique on \\ Israel and the Palestinians \\ Part II: The Media
}

\author{
ILAN PAPpé
}

The academic debate in Israel on Zionism and its implications for the way the society views itself and the "other" were discussed in part one of this article. This part examines the press, which with partial privatization and the cumulative impact of the Lebanon war and the intifada has undergone a transformation since the late 1980s. While a wider diversity of views and bold reporting on events are now current, the article concludes that the representation of the Palestinians and Arabs in the news columns is fundamentally unchanged. The last part will follow the manifestations of the academic debate in film, theater, novels, music, and poems and will assess the significance of these changes in the culture and worldview of Israeli society as a whole.

The Israeli cultural discourse on Zionism and the Palestinians has been transformed since the early 1980s. While the transformation has been most evident in academia, as demonstrated in the first part of this article, it has not been limited to the ivory tower but can be found in the press, literature, and the film industry. In fact, in theater and film, the transformation even predates the emergence of the "post-Zionist" academic debate. However, it was through the local print and electronic media that the scholarly debate moved from the universities to the public domain, encouraging more people in other cultural fields to rethink Zionism and its role in Israeli society.

\section{Peace Now and the Non-Zionist Left}

As was the case in academia, the "post-Zionist" challengers of the mainstream Zionist outlook in the other cultural arenas can be divided into two distinct groups, the principal difference between them being their willingness or unwillingness to question the fundamental assumptions of Zionism. They can therefore be termed the "Zionist Left" and the "non-Zionist Left," it being understood that "left" in Israel has come to mean a willingness in principle to give up territory for peace and to recognize the Palestinian right to self-determination, and has very little to do with a socialist point of view.

\footnotetext{
ILAN Pappe, professor of political science at Haifa University and academic head of the Institute for Peace Research Givat Haviva, is the author of The Making of the Arab-Israeli Conflict, 1947-1951, among other works.
} 
Members of the first group, who can be placed under the banner of the Peace Now movement, limit their criticism to post-1967 Israeli policy and conduct toward the Arab world in general and the Palestinians in particular. In this way they legitimize what the state, and before 1948 the Zionist movement, had done in the land of Palestine/Israel up to 1967. They adopt what might be called an Israel-centric or Judeocentric concern about the effect of the continued occupation of the Palestinian territories on Israel's "soul." The plight of the Palestinians is of secondary importance, if indeed it figures at all. Their desire for peace with the Palestinians derives more from a wish for an unbreachable separation from Palestinians than from any concern to redress a historical injustice or to end an immoral behavior. Their approach also ignores the implications of the presence of about a million Palestinians within the borders of pre-1967 Israel, a problem that will not be solved by the creation of a Palestinian state next to Israel. Indeed, members of this group avoid including the Palestinians of Israel in any discussion of the Palestine question. To do so could open a debate on Israel as a Jewish state, a topic no one in Peace Now is willing to address.

The second group consists of the more critical members of the Israeli Left, those more in line with the "new historians" who have challenged the standard Zionist version of the 1948 war. Because members of this group question Zionist behavior from the beginning of the movement in the $1880 \mathrm{~s}$, acknowledge a colonialist past in the movement's history, and are willing to reconsider the validity of the quest for a Jewish nation-state in what used to be geographic Palestine, they are referred to in Israel as "anti-Zionists" or "non-Zionists." Many of them express an explicit identification with the victims of Israeli occupation, and they are less interested in the moral dilemmas facing Israeli soldiers. In their political views, they tend to support the idea of Israel as a secular "state for all its citizens," in contrast to the Peace Now principle of Israel as a Jewish nation-state. Locating the two groups on the political map of Israel, one could say that the idea of a non-Jewish state is what Hadash stands for, while the Peace Now platform is that of Meretz.

Although it is important to distinguish between the Zionist Left and the non-Zionist Left, both groups have contributed to the post-Zionist discourse and to the fundamental change in the way Israelis view their past and present in general and to a transformation in the images and perceptions of the Palestinians in particular.

In the last year or so, the debate between the Zionist Left and the nonZionist Left, involving academics and nonacademics, has moved to the supplementary sections of the printed press and television talk shows-the same platforms on which, ten years ago, the academic debate was made public. The media thus continue to play the major role in airing the new post-Zionist views. Hence it is fitting to commence a survey of the developing post-Zionist discourse in various cultural domains by examining first the local press; literature, theater, and films will be dealt with in the part 3. 


\section{Israel's Press in Perspective}

The readiness of the Israeli media to open their doors to the new academic viewpoints can be understood as part of the ambiguous role the media plays in Israeli society. This can be seen when the local press is examined within a liberal-democratic context. Traditionally, it has acted in many ways like a state press in a nondemocratic environment, imposing restrictions on itself to an extent unparalleled in democratic countries.

This situation has deep historical roots. Legally, the press operates according to the emergency laws enacted by the British in 1945 , and subsequently adopted by Israel. Although these regulations have been used almost exclusively against the Palestinian citizens of Israel, ${ }^{1}$ they also have been used on rare occasions against the press (notably the closure of the Hebrew communist daily Qol Ha'Am in 1953 and of the daily Hadashot in

Traditionally, Israel's press has acted like a state press, imposing restrictions on itself to an extent unparalleled in democratic countries. 1984 , for which see below). In addition, the press devised its own code of conduct which subordinates the "right to know" to "security considerations" in times of national emergency. Furthermore, the freedom of the press has no legal basis in Israel in that there is no law guaranteeing its freedom to operate.

Until 1977, the press accepted the state's guidance in matters concerning foreign policy and defense. Thus, "sacred cow" topics such as Israel's "retaliatory" policy against the Arab states in the 1950s, its atomic policy in the late 1960 s, or its arms trade during the 1970 s never were dealt with. This consensual approach to "security" meant there was no need for the state to impose sanctions on any of the main newspapers. The same situation applied to the broadcast media. Indeed, until 1965 Radio Israel was part of the Prime Minister's Office; since 1965 both radio and television have been operated by a public firm that has an advisory board with representatives from several political parties. One of the main reasons for the smooth cooperation between the government and the press during Israel's first decades was the affiliation of most journalists to the Labor movement, which was in power from the creation of the state until 1977.

The ascension of the Likud to power created a schism between the more leftist press and the right-wing government. The press, for instance, did not accept, generally speaking, the Likud's aggressive settlement policy in the West Bank and the Gaza Strip and was not enthusiastic about the Lebanon war. However, this more vigorous criticism of government policy did not lead to any change in the basic approach to the "sacred cows" of defense and foreign policy. The press continues to be guided by a self-appointed committee of editors-in-chief that meets regularly with the military censor, accepting his advice on matters concerning his interpretation of state security. The committee, established in 1948, reviews every piece of information the press wants to publish concerning the army or the security services. It 
should be noted that this self-censorship has wide public support: Opinion polls have shown that the majority of the Jewish Israelis questioned favor limiting the media's freedom to report on "national security" issues. ${ }^{2}$ Overall, then, the press does not deviate from the Zionist consensus either in the tone of its reports or in the orientation of its lead articles.

Nor does the press, in its by and large dismissive presentation of Arabs in general and Palestinians in particular, deviate from the public consensus in Israel, where a decisive majority continues to regard the Israeli Palestinians as a "fifth column." The press still uses the term "Israeli Arabs," or even Beni Miutim ("members of minority groups"), the latter term having been coined in the early years of the state. When dealing with Jewish and Palestinian fatalities, whether caused by accident or an act of terrorism, the press employs different font sizes and places the items in more or less prominent sections of the newspaper, giving extended and careful detail where Jews are concerned and only brief and general references where Palestinian casualties are reported-even tragedy or loss has a different scale. Indeed, the very presence on newspaper staffs of "our special reporter on Arab affairs" to cover-albeit in a very limited and infrequent fashion-Arab politics within Israel underscores the segregation.

\section{Toward a Post-Zionist Media?}

But changes have been occurring in the Israeli press, as they have in academia. These changes have been facilitated by a partial privatization of the print and electronic media since the early 1990s. The three leading dailies, Ha'Aretz, Ma'ariv, and Yedi'ot Aharonot, are now owned by three families, and Israel's second TV channel is run by several

Privatization has turned the media into a kind of liberal watch dog, a function it had not fulfilled in the past. private companies that share time on the screen. This has turned the media into a kind of liberal watch dog, a function it had not fulfilled in the past. With a larger measure of free speech and opinion, the press has taken stands against human rights abuses within Israel, which concern Palestinians almost exclusively. The privatization also led to the first bold articles exposing corruption and financial embezzlement in the army and the security forces.

Another factor contributing to the change as of the late 1980s was the cumulative effect on the Israeli media and public of the nonconsensual war in Lebanon and the intifada. Although the intifada was launched at the end of 1987, it was not until 1989 that Israeli journalists, especially in the print media, began to report systematically what the national television and radio avoided presenting: the daily brutalities inflicted on the population in the occupied territories during the intifada. There were several reasons for this delay. As long as the national unity government was still in power, the press, with its pro-Labor orientation, was hesitant to criticize the IDF's actions in the territories; the right-wing coalition under Yitzhak Shamir that took over 
in 1989 was an easier target. Secondly, after being exposed mainly to the official version of events, Israelis gradually came to learn what was being said in the international media, and this had an important impact. Among the Israeli reporters who stand out for coverage hinting at another way of seeing Israel's reality are Gideon Levi of $\mathrm{Ha}^{\prime} \mathrm{Aretz}$, who brought to the Israeli reader the human tragedies arising from the continuing closures of the West Bank and Gaza Strip and their moral implications. In the same paper, columnist Amira Hess, who lived for three years in Gaza, made Israelis aware of life under occupation and has graphically conveyed the illusions and disappointment that the Oslo Accord generated there. ${ }^{3}$

In recent years, a few newspapers have also stood up to the military censor. Ha'Aretz, for example, has chosen on a number of occasions since the early 1990s not to cooperate with the censor. The now-defunct daily Hadashot had taken the lead in this respect, and as early as 1984 was closed for four days for disobeying a direct instruction not to publish a photograph of two captive Palestinian guerrillas who had hijacked an Israeli bus. The Shin Bet had objected to the photograph because it was the only evidence showing that the guerrillas, who were killed by the organization immediately after the photograph was taken, had been captured alive. ${ }^{4}$

In general, the print media are more advanced in their presentation of diverse views than the electronic media, particularly television, being less concerned about the ratings. ${ }^{5}$ The very division of the print media's information services into news sections, editorial and commentary sections by inhouse and guest contributors, and cultural and weekend supplements offers more scope for unconventional thinking, especially in the commentary and editorial sections. It was in the cultural supplements that the debates of the "new historians" and later of "post-Zionist" scholarship first appeared. In 1996, echoes of the debate were reflected in the editorial section, thereby enlarging the number of readers exposed to post-Zionist views. The debate also has moved to cultural programs on television which, despite their relatively low ratings, still reach a wider and more diverse audience.

The very inclusion of debates on post-Zionism in the print media and both television channels (albeit on educational programs) ${ }^{6}$ is indicative of a significant change compared to the past and indeed would have been inconceivable ten or fifteen years ago. The term "Palestinians in Israel" appears not only in the editorial columns and commentaries, but even in the article sections of the press. The term "post-Zionist"-used in both the positive and negative sense-is now in common usage in the local media. ${ }^{7}$

Nevertheless, one should not exaggerate the extent of the transformation in the press or its impact. The media is still a Zionist one, even if it allows post-Zionist voices now and then. The cases cited above are exceptions that do not disprove the general conduct, even of $\mathrm{Ha}^{\prime} \mathrm{Aretz}$. No matter how frequently articles criticizing the government's policy toward its own Palestinian citizens and toward the Palestinians of the occupied territories may appear in the editorial pages, the representation of the "other" in the news 
columns has not fundamentally changed. The "factual" news reports-on radio, television, and in print-continue to reflect an overall national agenda and employ a nationalistic discourse. Interviewers of Palestinians or Arab personalities, on TV and radio, continue to act as if they represent the government, or at least the consensual point of view. The press' approach to conflicting versions is well illustrated in the coverage of the September 1996 clashes in the occupied territories. Though almost unanimously critical of Netanyahu's decision to open the tunnel under the Haram al-Sharif, the press nonetheless took it for granted that the Palestinian Authority had ordered the police to fire on Israeli soldiers. The possibility, as reported in the international media, that the Palestinian police may have been moved to enter the fray by the spectacle of trigger-happy Israeli soldiers shooting at unarmed Palestinian protesters was not deemed credible in any of the major Israeli papers or TV programs.

The state of affairs characteristic of the Israeli media-a self-imposed national censorship on the one hand and an attempt to act as liberal marketplace of ideas on the other-produces a reality wherein the press serves two masters that are sometimes and indeed often at odds with one another: the "nation" and "freedom of speech." This reality feeds the self-image of the Israeli press as being a liberal organ without seeming unpatriotic. It is an intentional ambivalence, probably based on the reasonable assumption that the news sections are read more widely and are more influential than the columns and commentaries. Still, there has been some improvement. Several years ago, the Palestinian or Arab version of events was not mentioned at all; now it is mentioned at times, albeit with an obvious preference to "our" version.

It should be noted that attempts have been made to found newspapers that would project a different approach that entails not simply presenting a wide spectrum of views, as is now the case in the liberal mainstream press, but a different, integrated way of presenting the news-in short, a "postZionist" or "non-Zionist" approach to the way the news itself is covered and commented on. Most of these attempts have failed. Uri Avineri tried with Ha'Olam Ha'Zeh, but even his use of succulent gossip and unclad females did not help the paper survive: It was closed after many years in the early 1980 s as a financial failure. The idea of a tabloid press with an ideological, non-Zionist edge was then experimented with by Hadashot. As a daily paper, it presented a different discourse, more neutral and at times even radical-but it, too, was forced to close after four years because of financial problems. In a way, a local Jerusalem daily, Qol Ha'ir, is the only paper in Israel continuing a fair-minded-which in Israeli eyes means radical-reporting on daily events in the country and region.

Still, attempts at creating an alternative press continue today. A new weekly appeared last year, Mezad Sheni, which provides a Hebrew window not only on the official Palestinian position but especially on the opposition groups within the Palestinian political system. It is an interesting, but so far 
futile, attempt to create a common front between Hamas, Palestinian leftwing rejectionist organizations, Palestinians in Israel, Sephardic Jews in Development Towns, and feminist organizations. But if it is widely read-it is a weekly sent to interested people-it must serve as an eye opener for the conventional Israel reader. Recently, another paper, Socialism Now, came out with an anti-Zionist agenda; and a new monthly, Mitan (the Hebrew word for both an explosive device and burden), appeared in the beginning of 1997 with a similar agenda. Hadash is still publishing a weekly in Hebrew, Zoo Haderech [This is the way]. Time will tell whether any of these publications can reach a wider audience.

\section{Notes}

1. For a discussion of the imposition of the emergency rules, see David Kretzmer, The Legal Status of the Arabs of Israel (Tel Aviv: International Center for Peace in the Middle East, 1987).

2. This information and some other details on the legal status of the media have been taken from Dina Goren, "The Media in Israel," Skira Hodshit, no. 8-9 (August-September 1984), pp. 57-65 (in Hebrew). See also Pnina Lahav, "The Press and National Security" in National Security and Democracy in Israel, ed. Avner Yaniv (Boulder: Lynne Rienner, 1993), pp. 173-95.

3. Her book, To Drink from the Sea of Gaza, was published in Hebrew in 1996 (Tel Aviv: Hakibutz Ha-meuhad).

4. It was this incident, known as "the 300 Affair" in reference to the hijacked Bus no. 300, that eventually brought to light Shin Bet's practice of killing guerrillas taken captive and of lying to the prime minister and the judiciary when accused of acting against the law of the state. The event, which became the basis of a TV series shown on the first channel in January 1997, is described in the book by Yehiel Gutman, An Earthquake in the Shin Beth (Tel Aviv: Yedi'ot Aharonot, 1995) (in Hebrew).

5. Radio programs, likewise less dependent on ratings, are more open to a post-Zionist viewpoint.

6. The educational channel in Israel (Channel 23) and the "Science Channel" (Channel 8) have devoted two lengthy debates on post-Zionism (the first in September 1996 and the second in December 1996).

7. In a symposium on post-Zionism in Ha'Aretz, 15 October 1995, for example, Amnon Rubinstein, former minister of education and a leader of the Zionist Left, used the term to refer to scholars as being beyond the pale of legitimate debate on Israel's future. 